\section{$42-12125$}

$(0,-x-1$,

a 12

3. 32

1.
6

is $x^{2}$.

sistis

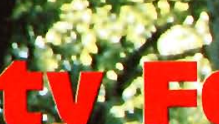

से $x^{2}{ }^{2}$

(5)

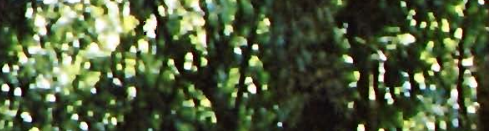

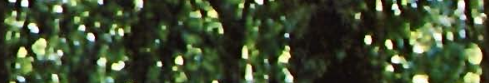

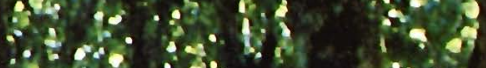

74. $\therefore x^{2}$ - bio

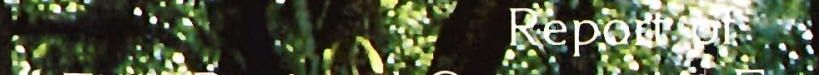

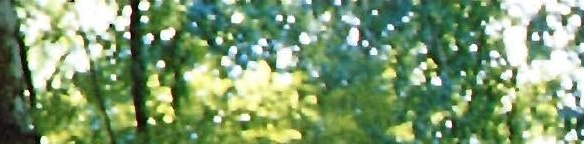

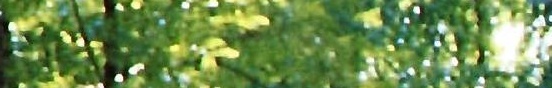

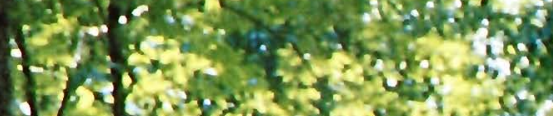

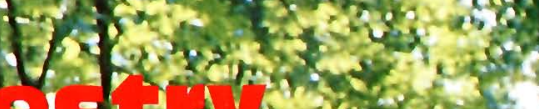

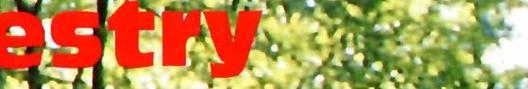

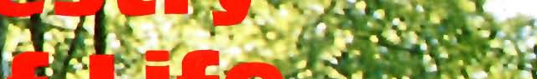

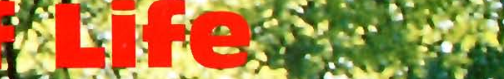

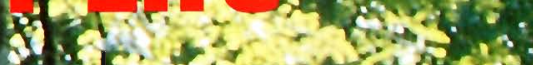

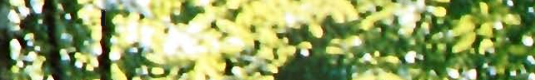

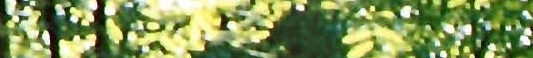

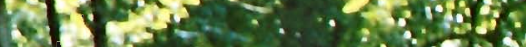

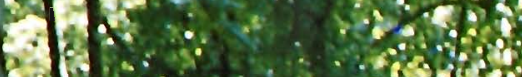

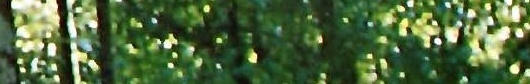

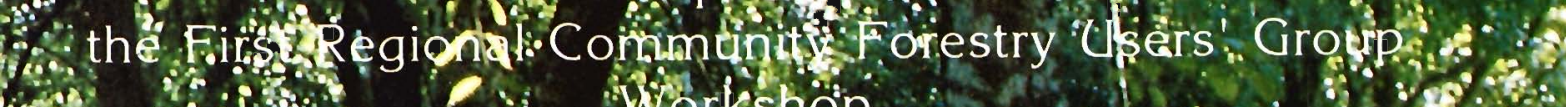

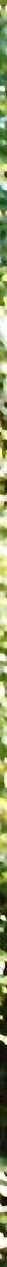

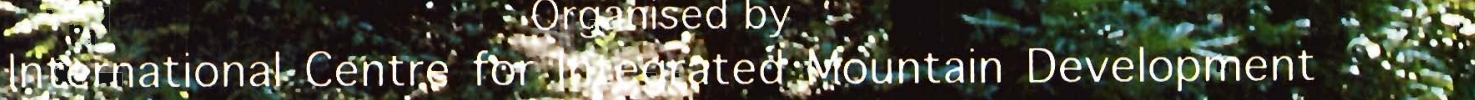

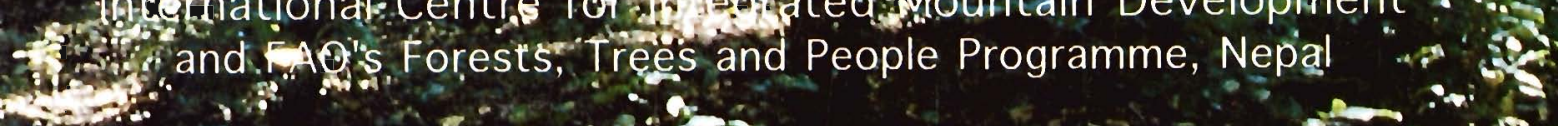

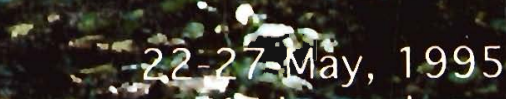

$$
\begin{aligned}
& \text { Kathmandu }
\end{aligned}
$$


Copyright (C) 1996

International Centre for Integrated Mountain Development

All rights reserved

ISBN: 92 9115-578-0

Published by

International Centre for Inlegrated Mountain Development

GPO Box 3226

Kathmandu, Nepal

Plates: Cover : The forest, the trees ............ Inset : Life-giving fodder

Page 71 : and the people

Typesetting at ICIMOD Publications' Unit

The views and interpretations in this paper are those of the author(s). They are not attributable to the International Centre for Integrated Mountain Development (ICIMOD) and do not imply the expression of any opinion concerning the legal status of any country, territory, city or area of its authorities, or concerning the delimitation of its frontiers or boundaries. 


\title{
Community Forestry The Language of Life
}

\author{
Report of \\ the First Regional Community Forestry Users' Group \\ Workshop
}

Organised by
International Centre for Integrated Mountain Development
and FAO's Forests, Trees and People Programme, Nepal

22-27 May, 1995

Kathmandu 


\section{Foreword}

"Community Forestry: The Language of Life", the title of this document, is an eloquent expression by one of the participants at this workshop of how community forestry has gained importance in planning for sustainable mountain development. Life and livelihood are intricately linked and the forest areas of the Hindu-Kush Himalayas remain a critical source of a diversity of products which make an invaluable contribution to household survival in mountain areas.

Within this context, participatory forest management has emerged as a key for sustainable management of forest resources in the Himalayas. While we recognise the role of government and non-government institutions in promoting this paradigm, mountain communities have played a major role in asserting their rights on forest resources, and women and men from the mountain areas have been at the forefront of forest management. The process of democratisation and decentralisation and the emergence of people-oriented approaches provide us with new opportunities to reflect on what strategies need to be evolved to unleash the latent potential of community-level institutions, so that they can grow into effective vehicles of mountain development.

It was with this objective that ICIMOD, in collaboration with FAO's Forestry, Trees and People Programme/WATCH, Nepal, organised the first regional community forestry users' group workshop. This six day workshop brought together women and men from the countries of the Hindu-Kush Himalayas and from Thailand and The Philippines, engaged in grassroot level forest management.

The workshop participants identified a number of key issues that would be necessary to make community forestry an effective mechanism for sustainable mountain development. These included evolving strategies for strengthening local institutions, establishing national and regional networks to enhance learning and knowledge exchange, building conceptual understanding of advocacy, and enhancing the role of community institutions in influencing policy. Strategies which will give women and the resource poor more control over natural resources' management received particular attention.

The forum went beyond being an opportunity to share experiences and identify barriers to community forestry and also evolved constructive approaches and strategies for the future, ensuring that leadership for such strategies remained vested with the representatives of community-level institutions. Several decisions were taken by participants from different countries to establish new institutional mechanisms and to strengthen existing ones from the perspectives they gained from the discussions.

ICIMOD's continuing support to these initiatives is within our dual mandate of environmental conservation and poverty alleviation. By linking environmental issues and economic aspirations, ICIMOD aims to assist in attaining sustainable development in the Hindu-Kush Himalayas. We hope that this workshop report will be useful to a wide audience of policy-makers, practitioners, and community-based institutions in their goal of sustainable and equitable development of our mountain areas.

I would like to use this opportunity to thank the Dholaka Ramechap Community Forestry Development Project of the Swiss Development Cooperation, Nepal, and the Ford Foundation, New Delhi, for providing financial support to this important workshop.

Egbert Pelinck

Director General 


\section{Acknowledgements}

The planning, design, and execution of a workshop which brings together women and men from community based institutions from seven countries for seven days provide a unique challenge. Innumerable institutions and individuals contributed to this forum and, while it is always difficult to name all of them, some deserve special mention.

First and foremost we would like to thank Narayan Kazi Shrestha of the Forestry Trees and People Programme/WATCH, Nepal, for his support to the idea of the workshop and in spending many hours and late nights in planning meetings and for his contribution during and after the workshop. It is appropriate also to express our thanks to the staff of WATCH who contributed in various ways to the workshop organisation.

Members of the core team who were involved in planning and, at the workshop, in facilitating different sessions made an invaluable contribution. We would specially like to thank Hukum Singh of the Nepal Australia Community Forestry Project; Ghanendra Kafle of the Nepal UK Community Forestry Project and Patrick Robinson and Khagendra Siktel of the Dholaka Ramechap Community Forestry Development Project of the Swiss Development Cooperation, Nepal.

Cor Veer, Asia Coordinator, Forestry Trees and People Programme, contributed by expanding the regional participation to the workshop by providing financial support to participants from Thailand and the Philippines who provided an added dimension to the workshop.

The wall newspaper, Chautari, which was produced daily at the workshop became popular as a vehicle of communication. For producing this and for film documentation of the workshop we would like to thank Mohan Mainali, Dhruba Basnet, Mohan Bista, Hasta Gurung, Ramesh Dhamala, and Pramesh Bhandary of the Nepal Forum of Environmental Journalists, Nepal.

Manjul Nepal needs to be mentioned specially for coordinating the evenings of song, poetry and dance which created a participatory environment during the workshop and bridged whatever gaps existed amongst participants from different countries. We would also like to thank the team at Sarwanam who specially designed and performed a relevant street play for the workshop participants.

The challenge of translation, rapporting, and putting together a cohesive document to capture the workshop proceedings was tremendous and was ably met by Judith Amtzis, Nivedita Mishra, Rajiv Singh, Shashi Khadgi, Kiran Basnet and Tribhuvan Paudel. Without their diligent support and commitment it would not have been possible to produce this report.

We would specially like to thank the Principal of Budhanilkantha School for making available the school facilities and their beautiful campus to us. Lt. Colonel B.J. Shah, Bursar was extremely helpful and without his cooperation the workshop would not have been possible. We would also like to thank all the Budhanilkantha School staff who assisted with logistics, housekeeping, and catering services. 
It is extremely difficult to name all my colleagues at ICIMOD who assisted in setting up this workshop. We would like to specially thank Sameer Karki for planning and facilitation and Reeta Rana and Gobind Shrestha for organisational and secretarial support. Apart from them, we would like to express our appreciation of all the other logistics and administration departments without whose cooperation it would have been impossible to organise this workshop. Last, but not least, it would be opportune to thank the professionals in our publications department who were instrumental in editing and producing this document.

\author{
Anupam Bhatia \\ Regional Coordinator \\ Participatory Natural Resources' Management Programme
}




\section{Contents}

Foreword

Acknowledgements

Introduction

Introduction

Participants

Workshop Process

Workshop Communication

File Documentation

Opening Sessions

Registration, Orientation, Poster Sessions

Opening Plenary Session

Cross-country Working Groups

Informal Inauguration

Formal Inauguration

Plenary Sessions

Working Group Reports

Working Group One

Working Group Two

Working Group Three

Working Group Four

Sarwanam Street Theatre

Field Trips

Country Group Presentation

The Philippines

Thailand

Bhutan

Pakistan

India

Nepal

Concurrent Sessions

Challenges for the Future 
Strategies for Strengthening Local Institutions:

Institution-building, Capacity-building and Training

Strategies for Enabling Policy, Rules, and Regulations

Country Action Plans and Strategies

Pakistan

Bhutan

56

Thailand

57

The Philippines

India

58

Nepal

ICIMOD to Introduce Regional Newsletter for

Community Forestry Users' Groups

Closing Plenary

Annexes

Workshop Schedule 